\title{
Weed Management by Rice Straw Mulching in Direct Seeded Lowland Rice (Oryza sativa L.)
}

\author{
D.A.U.D. Devasinghe, K.P. Premarathne ${ }^{1 *}$ and U.R. Sangakkara ${ }^{1}$ \\ Department of Plant Sciences, Faculty of Agriculture \\ Rajarata University of Sri Lanka \\ Puliyankulama, Anuradhapura
}

Sri Lanka

\begin{abstract}
Direct seeding of rice (Oryza sativa L.) induces the production of greater grain yields in water deficit areas. However, weeds pose a serious threat to sustainability of yield of direct-seeded rice. This field study evaluated the effectiveness of rice straw mulch on managing weed populations and increasing yields of direct wet-seeded (DWSR) and direct dry-seeded rice (DDSR) in 2009 Yala (DS) and 2009/2010 Maha (WS) seasons in a principal rice growing region of Sri Lanka. The major weeds associated with DDSR in DS were Cyperus rotundus, Isachne globosa and Leptochloa chinensis. In DWSR, the dominant species were Cyperus rotundus, Echinochloa crus-galli and Isachne globosa. The weed density was reduced in the WS and the major weeds were Cyperus rotundus, Echinochloa crus-galli and Isachne globosa. In both systems Cyperus rotundus was the most dominant weed species in all treatments based on the summed dominance ratio. The rice straw mulch was effective in weed management under DWSR, but not in DDSR. The grain yield was inversely correlated with increasing weed biomass and weed density in both systems. Compared to DWSR, chemical weeding which is the present practice in Sri Lanka, yield gains of $9.23 \%$ and $5.74 \%$ were achieved in DWSR with a straw mulch and a yield loss of $49.88 \%$ and $22.24 \%$ in the DDSR with the same treatment in DS and WS, respectively. The study indicated the possibility of suppressing weeds in direct wet-seeded land low rice with straw mulch in both seasons.
\end{abstract}

Key words: Direct dry-seeding, direct wet-seeding, grain yield, rice straw mulch, weed management

\section{INTRODUCTION}

Rice (Oryza sativa L.), the staple food crop for about half of the world population, is mainly grown in South and South-east Asia. There are three principal methods of rice establishment: dry seeding, wet seeding, and transplanting. Although these methods vary, each one is characterized by distinct features. Dry seeding consists of sowing dry seeds onto dry (unsaturated) soils. Seeds can be broadcast, drilled, or dibbled. Wet seeding involves sowing pre-germinated seeds onto wet (saturated) puddled soils. Transplanting involves replanting of rice seedlings grown in nurseries into puddled soils. When seeds are sown directly, the dryand wet-seeding methods are often jointly referred to as direct seeding. Recently, in response to rising labor costs, competitive demand for water and the need to intensify crop production, many Asian farmers have shifted from transplanting to direct seeding of rice (Pandey and Velasco, 1999).

To whom correspondence should be addressed: kp.premaratne@gmail.com

Department of Crop Science, Faculty of Agriculture, University of Peradeniya, Peradeniya, Sri Lanka 
Direct-seeding methods have several advantages over transplanting. Depending on the nature of the production system, direct seeding can reduce labor requirements by approximately $50 \%$. In situations where no substantial reduction in labor requirement occurs, direct seeding can still be beneficial because the demand for labor is spread over a longer time than with transplanting, which needs to be completed within a short time. (Singh et al., 1994).

Cost of weed control could be a major constraint to the widespread adoption of directseeding methods, especially dry seeding. The key to the success of direct-seeded rice is the availability of efficient weed control techniques (Pandey and Velasco, 1999). Many farmers depend on herbicides for weed control. However, weed species resistant to herbicides have been reported in countries with high adoption rates of direct seeding. These include the Philippines (Migo et al.,1986), Malaysia (Watanabe et al., 1997), Japan (Itoh et al., 1999) and Korea (Park et al., 1999). In the USA, multiple resistance to several chemical classes of herbicides has occurred in a single weed species commonly found in rice fields in California (Fischer et al., 2000). In addition, public are more concerned about negative effects of herbicides on the environment and human health. Water pollution (Cornacchia et al., 1984), injuries to beneficial organisms (Stoskopf, 1985) and adjacent crops (Hill and Hawkins, 1996) are a few consequences of using herbicides. Therefore, there is a need to develop sustainable weed management approaches by integrating a variety of agronomic practices to suppress weeds and minimize herbicide use.

A rice crop yields a large amount of straw, which from the standpoint of health and environmental pollution, is one of the most critical problems in rice producing countries (FAO, 1982). A major portion of it is combusted on fields causing a great hazard to public health and the environment. Therefore, considerable attention has been placed on using straw in composting and feeding animals as it is cheap and abundant (Abdelhamid et al., 2004). However, Mendoza (1989) demonstrated that recycling rice straw could substitute $2-4$ bags of fertilizers per hectare per cropping or supply $2.5 \mathrm{~kg} \mathrm{~N}$ per ton of straw (Watanabe, 1978). Moreover, new approaches of using rice straw for controlling weeds in different crops have been suggested by Mendoza and Samson (1999) who indicated that rice straw can be used for mulching, which prevents weed growth and supplies organic matter for heterotrophic Nfixing microorganisms, which could be utilized by succeeding crops (Patnaik, 1978).

Limited research data are available on the proportion of rice area established by different methods and the use of rice straw mulch in rice weed control in Sri Lanka. Therefore, this study was carried out to determine the effects of rice straw mulch and chemical weeding on suppressing weeds in direct dry and direct wet seeded land low rice cultivated in one of the principal rice growing area in Sri Lanka. This study aims to contribute to the development of sustainable integrated weed management systems and seek the possibility of minimizing herbicide use in direct seeded rice cultivation.

\section{MATERIALS AND METHODS}

Field experiments were conducted in the rice fields of the research unit of the Faculty of Agriculture, Rajarata University of Sri Lanka, Puliyankulama in the Anuradhapura district during 2009 Yala (dry) (DS) and 2009/10 Maha (wet) season: (WS). A randomized complete block design (RCBD) with six treatments and three replications was used in both seasons. The rainfall in 2009 DS and 2009/10 WS experimental periods were $79.5 \mathrm{~mm}$ and $650.4 \mathrm{~mm}$, respectively. The plot size was $6 \times 3 \mathrm{~m}^{2}$. The six treatments included direct dry seeded rice (DDSR) or direct wet seeded rice without weeding (UW), with rice straw mulch (RSM), or with chemical weeding $(\mathrm{C})$. 
Land was prepared after impounding water with two ploughings, one harrowing followed by fine leveling in the DWSR method while in the DDSR method, the soil was moistened followed by one ploughing, one harrowing and rough leveling. Pre-germinated seeds of variety BG 352 were broadcasted at a seed rate of $55 \mathrm{~kg} / \mathrm{ha}$ in the DWSR method to the puddeled soil. In contrast, in the DDSR method, non-germinated seeds of the same variety at the same rate were sown on moist beds made up from non-puddled soil. The air dried rice straw of BG 352 from the previous crop was used as the mulch. Just after seeding, the rice straw was spread homogenously onto the soil surface at the rate of $4 \mathrm{t} / \mathrm{ha}$. Chemical weeding was practiced using Ethoxysulfuron $20+$ fenoxaprop $69 \mathrm{~g}$ a.i./L (Tiller ${ }^{\circledR}$ Gold) at a rate of 0.5 L/ha after 10-14 days of sowing.

The soils were moistened two times, until seedling emergence in DDSR plots. Thereafter, all the plots were irrigated at 5 day intervals and water was kept at a level of 2-3 cm until crop maturity. Fertilizer was applied at a rate of 262.5-87.5-75 $\mathrm{kg} \mathrm{NPK} \mathrm{ha}^{-1}$. The phosphate fertilizer was added as a basal dressing before seeding. Nitrogen fertilizer was applied in four splits, $12.5 \mathrm{~kg} / \mathrm{ha}$ at seeding, $75 \mathrm{~kg} / \mathrm{ha}$ at 14 days after sowing, $125 \mathrm{~kg} / \mathrm{ha}$ at 35 days after sowing and $50 \mathrm{~kg} / \mathrm{ha}$ at panicle initiation stage. Potassium fertilizer was applied in two splits, $37.5 \mathrm{~kg} / \mathrm{ha}$ at seeding and $37.5 \mathrm{~kg} / \mathrm{ha}$ at panicle initiation stages as recommended by the Department of Agriculture, Sri Lanka.

Weed samples were taken at 28, 35 days after sowing and at panicle initiation, 50\% heading and harvesting stages to determine the weed density and dry weights. The dominant weed species was determined at $50 \%$ heading. At these sampling dates, four quadrates of $0.5 \mathrm{~m} \mathrm{x}$ $0.5 \mathrm{~m}$ were randomly selected in each plot. Sampled weeds were classified according to species, counted, and dried in an oven $\left(70^{\circ} \mathrm{C}\right.$ for $\left.48 \mathrm{~h}\right)$ to a constant weight. The contribution of individual weed species to the weed community was determined by the two factor Summed Dominance Ratio (SDR) calculated using relative density (RD) and relative dry weight (RDW) (Numata, 1971) as follows:

$$
\begin{gathered}
\mathrm{SDR}=\frac{\mathrm{RD}+\mathrm{RDW}}{2} \\
\mathrm{RD} \%=\frac{\text { Density of a given species }}{\text { Total density of all species }} \times 100 \\
\mathrm{RDW} \%=\frac{\text { Dry weight of a given species }}{\text { Total density of all species }} \times 100
\end{gathered}
$$

Sampling was carried out at harvest for yield components (panicle density, number of spikelets per panicle, percentage of filled spikelets, 1000-grain weight). The samples were collected from four sampling areas of $0.5 \mathrm{~m} \times 0.5 \mathrm{~m}$ (total $1 \mathrm{~m}^{2}$ for four samples) in each plot. In addition, the grain yield (adjusted to 14\% moisture content) was determined at harvest using the yield components (Yoshida, 1981) obtained.

Yield $=\left(\begin{array}{l}\text { Numberof panicles per unit area } \times \text { Numberof spikelets per panicle } \times \% \text { Grain filling } \\ \times \text { thousand grain weight }\end{array}\right)$ 
Analysis of variance and covariance was carried out for the collected data using the SAS statistical analytical package (version 8.12, SAS Institute, Cary, NC). Means were tested for significant differences by the Duncan's test.

\section{RESULTS AND DISCUSSION}

\section{Weed community dominance}

The major weeds associated with DDSR in the 2009 DS were Cyperus rotundus, Isachne globosa and Leptochloa chinensis while in DWSR the major weeds were C. rotundus, Echinochloa crus-galli and Isachne globosa. The weed population density was reduced in the 2009/2010 WS and the major weeds were C. rotundus, E. crus-galli and I. globosa in DDSR and DWSR methods. Among the weed species, C. rotundus was found to be the most dominant species representing the highest SDR in all treatments (Tables 1 and 2). SDR of $C$. rotundus in DDSR-UW, DDSR-RSM, DDSR-C, DWSR-UW, DWSR- RSM and DWSR-C treatments were $65.49 \%, 88.99 \%, 79.22 \%, 60.45 \%, 92.82 \%$ and $72.10 \%$ respectively in the 2009 DS. The respective values in $2009 / 10$ WS were $65.18 \%, 100 \%, 100 \%, 38.89 \%$ and $68.36 \%$. Weeds species could not be identified in DWSR with chemical weeding in $2009 / 10$ WS. The contribution of the other species to the weed community was negligikle (Tables 1 and 2). Although the application of rice straw mulch helps to control seed propagated weeds up to a certain extent, it is not very effective in controlling rhizomatous weeds such as $C$. rotundus in DDSR method.

Table 1. Weed species, weed density and weed dry weight recorded in the experimental plots at 50\% heading stage in 2009 DS

\begin{tabular}{|c|c|c|c|c|c|c|}
\hline Treatment & Type & Weed species & Family & $\begin{array}{c}\text { Weed } \\
\text { plants/ } \\
\mathbf{m}^{2}\end{array}$ & $\begin{array}{c}\text { Dry } \\
\text { weight/ } \\
\mathbf{m}^{2}\end{array}$ & SDR \\
\hline \multirow[t]{9}{*}{ DDSR-UW } & \multirow[t]{3}{*}{$S$} & \multirow{3}{*}{$\begin{array}{l}\text { Cyperus rotundans L. } \\
\text { Fimbristylis miliacea } \\
\text { (L.) vahl. } \\
\text { Cyperus iria L. }\end{array}$} & Cyperaceae & 627 & 645.48 & 65.49 \\
\hline & & & Cyperaceae & 48 & 48.12 & 4.94 \\
\hline & & & Cyperaceae & 34 & 25 & 3.01 \\
\hline & \multirow[t]{4}{*}{$G$} & \multirow{3}{*}{$\begin{array}{l}\text { Isachne globosa } \\
\text { (thumb.)kuntz. } \\
\text { Leptochloa chinensis L. } \\
\text { Echinochloa crus-galli (L) } \\
\text { P. Beauv }\end{array}$} & Poaceae & 80 & 107.55 & 9.71 \\
\hline & & & Poaceae & 80 & 74.94 & 7.96 \\
\hline & & & Poaceae & 49 & 43.21 & 4.73 \\
\hline & & Ischaemum rugosum Salisb. & Poaceae & 14 & 18.23 & 1.67 \\
\hline & \multirow[t]{2}{*}{$B L$} & Commelina diffusa Burm.f & Commelinaceae & 35 & 18.32 & 2.70 \\
\hline & & Marselia quadrifolia L. & Marsiliaceae & 9 & 5.22 & 0.72 \\
\hline \multirow[t]{4}{*}{ DDSR-RSM } & $S$ & \multirow{2}{*}{$\begin{array}{l}\text { Echinochloa crus-galli (L) } \\
\text { P. Beauv }\end{array}$} & Cyperaceae & 688 & 592.6 & 88.99 \\
\hline & \multirow[t]{2}{*}{$G$} & & Poaceae & 9 & 18.65 & 1.99 \\
\hline & & $\begin{array}{l}\text { Isachne globosa } \\
\text { (thumb.)kuntz. }\end{array}$ & Poaceae & 6 & 13.99 & 1.44 \\
\hline & $B L$ & Commelina diffusa Burm.f & Commelinaceae & 35 & 36.37 & 5.00 \\
\hline \multirow[t]{3}{*}{ DDSR-C } & \multirow[t]{2}{*}{$S$} & Cyperus rotundans L. & Cyperaceae & 319 & 208.93 & 79.22 \\
\hline & & Cyperus iria $\mathrm{L}$ & Cyperaceae & 30 & 17.17 & 7.00 \\
\hline & $G$ & Echinochloa crus-galli (L) & Poaceae & 10 & 51.36 & 10.54 \\
\hline
\end{tabular}




\begin{tabular}{|c|c|c|c|c|c|c|}
\hline \multirow{11}{*}{ DWSR- UW } & \multirow{4}{*}{$\begin{array}{l}B L \\
S\end{array}$} & \multicolumn{5}{|l|}{ P. Beauv } \\
\hline & & Commelina diffusa $\mathrm{L}$. & Commelinaceae & 14 & 0.53 & 1.92 \\
\hline & & \multirow{2}{*}{$\begin{array}{l}\text { Cyperus rotundans L. } \\
\text { Fimbristylis miliacea } \\
\text { (L.)vahl. }\end{array}$} & Poaceae & 788 & 735.38 & 60.45 \\
\hline & & & Poaceae & 102 & 109.86 & 8.35 \\
\hline & \multirow{5}{*}{$G$} & \multirow{2}{*}{$\begin{array}{l}\text { Cyperus difformis L. } \\
\text { Echinochloa crus-galli (L) } \\
\text { P. Beauv }\end{array}$} & Cyperaceae & 26 & 39.16 & 2.53 \\
\hline & & & Poaceae & 80 & 210.9 & 11.02 \\
\hline & & $\begin{array}{l}\text { Isachne globosa } \\
\text { (thumb.)kuntz. }\end{array}$ & Poaceae & 62 & 182.3 & 9.22 \\
\hline & & Leptochloa chinensis L. & Poaceae & 31 & 75.3 & 4.04 \\
\hline & & Ischaemum rugosum Salisb & Poaceae & 8 & 12.3 & 0.79 \\
\hline & \multirow[t]{2}{*}{$B L$} & Commelina diffusa Burm.f & Commelinace & 60 & 23.28 & 3.43 \\
\hline & & Marselia quadrifolia L. & Marsiliaceae & 19 & 6.1 & 1.04 \\
\hline \multirow[t]{3}{*}{ DWSR-RSM } & $S$ & \multirow{2}{*}{$\begin{array}{l}\text { Cyperus rotundans L. } \\
\text { Echinochloa crus-galli (L) } \\
\text { P. Beauv }\end{array}$} & Cyperaceae & 380 & 167.0 & 92.82 \\
\hline & $G$ & & Poaceae & 9 & 3.04 & 1.94 \\
\hline & $B L$ & Commelina diffusa Burm.f & Commelinace & 31 & 5.44 & 5.24 \\
\hline \multirow[t]{3}{*}{ DWSR-C } & $S$ & \multirow{2}{*}{$\begin{array}{l}\text { Cyperus rotundans L. } \\
\text { Echinochloa crus-galli (L) } \\
\text { P. Beauv }\end{array}$} & Cyperaceae & 86 & 72.6 & 72.10 \\
\hline & $G$ & & Poaceae & 12 & 17.87 & 14.11 \\
\hline & $B L$ & Commelina diffusa Burm.f & Commelinace & 28 & 5.17 & 13.82 \\
\hline
\end{tabular}

DDSR, direct dry-seeded rice; DWSR, direct wet-seeded rice; UW, without weeding; C, chemical; RSM, rice straw mulch; S, sedges; G, grasses; BL, broad leaves; DS, dry season; S, sedges; G, grasses and BL, broad leaves

Table 2. Weed species, weed density and weed dry weight recorded in the experimental plots at $50 \%$ heading stage in $2009 / 10 \mathrm{WS}$

\begin{tabular}{|c|c|c|c|c|c|c|}
\hline Treatment & Type & Weed species & Family & $\begin{array}{c}\text { Weed } \\
\text { plants } / \mathbf{m}^{2}\end{array}$ & $\begin{array}{c}\text { Dry } \\
\text { weight } / \mathbf{m}^{2}\end{array}$ & SDR \\
\hline \multirow[t]{4}{*}{ DDSR-UW } & $S$ & \multirow{2}{*}{$\begin{array}{l}\text { Cyperus rotundans L. } \\
\text { Isachne globosa } \\
\text { (thumb.)kuntz. }\end{array}$} & Cyperaceae & 111 & 70.83 & 65.18 \\
\hline & \multirow[t]{3}{*}{$G$} & & Poaceae & 24 & 38.58 & 23.59 \\
\hline & & $\begin{array}{l}\text { Echinochloa crus-galli } \\
\text { (L) P. Beauv }\end{array}$ & $i$ Poaceae & 11 & 15.23 & 9.81 \\
\hline & & Ischaemum rugosum & Poaceae & 7 & 5.31 & 4.45 \\
\hline DDSR-RSM & $S$ & Cyperus rotundans L. & Cyperaceae & 75 & 159.93 & 100.00 \\
\hline DDSR-C & $S$ & Cyperus rotundans L. & Cyperaceae & 40 & 55.57 & 100.00 \\
\hline \multirow[t]{3}{*}{ DWSR-UW } & $S$ & Cyperus rotundans $\mathrm{L}$. & Cyperaceae & 42 & 42.29 & 38.89 \\
\hline & \multirow[t]{2}{*}{$G$} & $\begin{array}{l}\text { Echinochloa crus-galli } \\
\text { (L) P. Beauv }\end{array}$ & ${ }^{i}$ Poaceae & 24 & 23.21 & 21.81 \\
\hline & & $\begin{array}{l}\text { Isachne globosa } \\
\text { (thumb.) kuntz. }\end{array}$ & Poaceae & 36 & 51.29 & 39.77 \\
\hline \multirow[t]{2}{*}{ DWSR-RSM } & $S$ & Cyperus rotundans L. & Cyperaceae & 5 & 7.57 & 68.36 \\
\hline & $G$ & $\begin{array}{l}\text { Echinochloa crus-galli } \\
\text { (L) P. Beauv }\end{array}$ & $i$ Poaceae & 1 & 6.6 & 31.61 \\
\hline
\end{tabular}

DDSR, direct dry-seeded rice; DWSR, direct wet-seeded rice; UW, without weeding; C, chemical; RSM, rice straw mulch; S, sedges; G, grasses; BL, broad leaves and WS, wet season 


\section{Weed dry weight}

Total weed dry weight was significantly reduced due to chemical weeding and rice straw mulch in the DWSR method compared to the un-weeded plots (Table 3). In both seasons, a significantly low total weed biomass was recorded in DWSR rice straw mulch and DWSR chemical weeded plots. The application of rice straw mulch was not very effective in weed control in the DDSR method as shown by the significantly high weed biomass at 28 and 35 days after sowing, panicle initiation, 50\% heading and harvesting stage in DS compared to the DDSR chemical weeded plots. A similar comparison in the DDSR method in 2009/2010 WS showed a significant difference in weed biomass at panicle initiation and $50 \%$ heading stages. In both seasons, promising weed management could be seen in the DDSR method with chemical application.

Table 3. Weed dry weight as affected by method of crop establishment and weed management in 2009 DS and 2009/2010 WS

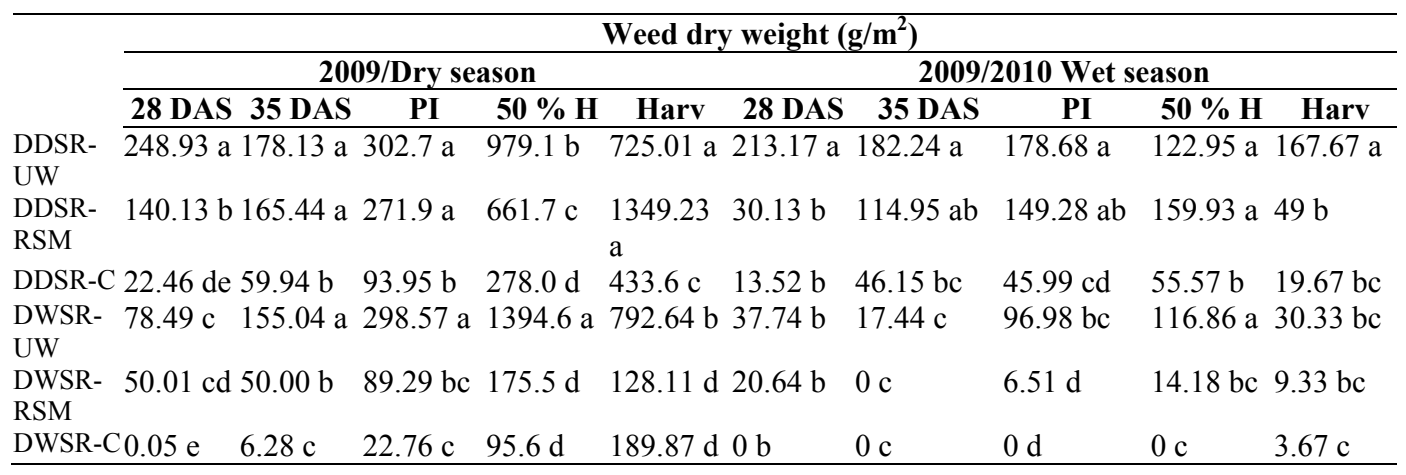

DDSR, direct dry seeded rice; DWSR, direct wet seeded rice; UW, without weeding; C, chemical; RSM, rice straw mulch; DAS, days after sowing; PI, panicle initiation; H, heading; Harv, harvesting; DS, dry season and WS, wet season. , values within a column followed by a common letter are not significantly different at $5 \%$ level.

Therefore, the application of rice straw mulch at the time of crop establishment in DWSR results in suppressing growth and development of a wide range of weeds. This could be due to the physical barrier or due to allelopathic effect of rice straw against developmental processes and progression of associated weeds. The allelopathy effect could be due to the release of certain phytotoxic compounds by rice straw which in aid of the other agroecosystem factors, have the ability to accumulate in the soil in sufficient amounts and probably with sufficient persistence to cause a remarkable reduction in weed growth. Hassan et al. (1998) found that several rice cultivars strongly inhibited $(30-90 \%)$ the growth and development of E. crus-galli and $C$. difformis under field conditions, suggesting that allelopathic effect of rice cultivars could play a key role in weed control under field conditions as they can actively release certain phytotoxins. However, Fujii (1992) reported that the allelopathic activity in rice cultivars was species-specific and depended on the concentration and composition of the phytotoxic components (Ebana et al., 2001). Recently, Chung et al. (2003) found that rice straw was the most effective method for controlling the most problematic weed in rice (barnyard-grass, E. crus-galli). 


\section{Weed density}

Weed management by rice straw mulch or chemical weeding significantly affected weed density (total of all species) in DDSR and DWSR compared to their un-weeded plots in both seasons (Table 4).

Table 4. Weed density as affected by method of crop establishment and weed management in 2009 DS and 2009/2010 WS.

\begin{tabular}{|c|c|c|c|c|c|c|c|c|c|c|}
\hline & \multicolumn{10}{|c|}{ Weed density (plants $/ \mathbf{m}^{2}$ ) } \\
\hline & \multicolumn{5}{|c|}{ 2009/Dry season } & \multicolumn{5}{|c|}{ 2009/2010 Wet season } \\
\hline & $\begin{array}{c}28 \\
\text { DAS }\end{array}$ & $\begin{array}{c}35 \\
\text { DAS }\end{array}$ & PI & $\begin{array}{c}50 \% \\
\text { H }\end{array}$ & Harv & $\begin{array}{c}28 \\
\text { DAS }\end{array}$ & $\begin{array}{c}35 \\
\text { DAS }\end{array}$ & PI & $\begin{array}{c}50 \% \\
\text { H }\end{array}$ & Harv \\
\hline DDSR-UW & 813 & 609 & 860 & 976 & 1504 & 481 & 458 & 252 & 153 & 86 \\
\hline DDSR-RSM & 400 & 152 & 627 & 738 & 1486 & 111 & 197 & 220 & 75 & 77 \\
\hline DDSR-C & 75 & 75 & 278 & 373 & 483 & 48 & 101 & 61 & 40 & 19 \\
\hline DWSR-UW & 746 & 765 & 617 & 1156 & 1022 & 313 & 189 & 81 & 102 & 60 \\
\hline DWSR-RSM & 450 & 356 & 536 & 420 & 200 & 6 & 0 & 5 & 6 & 14 \\
\hline DWSR-C & 0 & 38 & 141 & 126 & 447 & 0 & 0 & 0 & 0 & 6 \\
\hline
\end{tabular}

DDSR, direct dry seeded rice; DWSR, direct wet seeded rice; UW, without weeding; C, chemical; RSM, rice straw mulch; DAS, days after sowing; PI, panicle initiation; H, heading; Harv, harvesting; DS, dry season and WS and wet season

At the harvesting stage in the 2009 DS, in DDSR and DWSR un-weeded plots had 1504 weed plants $/ \mathrm{m}^{2}$ and 1022 weed plants per $\mathrm{m}^{2}$ in 2009 DS. The comparable figures in WS were 86 and 60 weeds $/ \mathrm{m}^{2}$. The abundant availability of water in WS significantly reduced the density of weeds. In the DS, at harvesting stage in the DDSR rice straw mulch plots had 1486 weed plants $/ \mathrm{m}^{2}$ while in DWSR rice straw mulch plots had 200 weed plants $/ \mathrm{m}^{2}$. The comparable figures in WS were 77 and 14 weed plants $/ \mathrm{m}^{2}$ respectively. Hence, although the application of rice straw mulch was effective in the reduction of weed density in the DWSR, it was not very effective in weed density reduction in the DDSR method. In contrast, due to chemical weeding in the DDSR method, the weed density was reduced to 483 in DS and 19 weed plants $/ \mathrm{m}^{2}$ in WS at the stage of harvesting. Therefore, chemical weeding developed an effective weed control in the DDSR.

\section{Rice grain yield}

Method of crop establishment and weed management had a significant influence on rice grain yield in both seasons. Significantly high rice grain yields were achieved in DWSR with the rice straw mulch, DWSR with chemical weeding and DDSR with chemical weeding (Table 5). Although the application of rice straw mulch was effective in weed management in the DWSR in both seasons, it was not very effective in weed management in the DDSR method (Table 3). Hence, a significantly high grain yield was obtained in DWSR than in the DDSR methods with the application of rice straw mulch at the rate of $4 \mathrm{t} / \mathrm{ha}$. This could be attributed to the lower weed numbers in DWSR plots (Table 4). 
Table 5. Rice grain yield as affected by method of crop establishment and weed management in 2009 DS and 2009/10 WS.

\begin{tabular}{lcccc}
\hline Treatments & \multicolumn{2}{c}{ Rice grain yield t/ha } & \% Yield loss/gain compared to DSSR-C \\
\hline & $\mathbf{2 0 0 9} \mathbf{~ D S}$ & $\mathbf{2 0 0 9 / 1 0 ~ W S}$ & $\mathbf{2 0 0 9} \mathbf{~ D S}$ & $\mathbf{2 0 0 9 / 1 0 ~ W S}$ \\
\cline { 2 - 5 } DDSR-UW & $4.37 \mathrm{~b}$ & $3.18 \mathrm{c}$ & $-45.71 \%$ & $-47.78 \%$ \\
DDSR- & $4.02 \mathrm{~b}$ & $4.29 \mathrm{~b}$ & $-49.88 \%$ & $-22.48 \%$ \\
RSM & & & & \\
DDSR-C & $7.03 \mathrm{a}$ & $5.75 \mathrm{a}$ & $-12.34 \%$ & $-4.24 \%$ \\
DWSR-UW & $4.65 \mathrm{~b}$ & $3.81 \mathrm{bc}$ & $-42.02 \%$ & $-28.43 \%$ \\
DWSR- & $8.76 \mathrm{a}$ & $6.55 \mathrm{a}$ & $+9.23 \%$ & $+5.74 \%$ \\
RSM & & & & - \\
DWSR-C & $8.02 \mathrm{a}$ & $6.09 \mathrm{a}$ & - & - \\
\hline
\end{tabular}

DDSR, direct dry-seeded rice; DWSR, direct wet-seeded rice; UW, without weeding; C, chemical; RSM, rice straw mulch; DS, dry season; WS, wet season In a column, values followed by a common letter are not significantly different at $5 \%$ level.

Compared to DWSR with chemical weeding which is the normal practice in Sri Lanka, a yield loss was recorded in dry and wet seasons respectively $(45.71 \%$ and $47.78 \%$ in unweeded DDSR, $49.88 \%$ and $22.24 \%$ in DDSR with the rice straw mulch, $12.34 \%$ and $4.24 \%$ in DDSR with chemical weeding and $42.02 \%$ and $28.43 \%$ in un-weeded DWSR). However, rice yield gain of $9.23 \%$ and $5.74 \%$ could be observed respectively in DS and WS in DWSR with the rice straw mulch (Table 4). The higher yield in the DWSR treatment in the WS could be due to the longer presence of the mulch in this season (i.e. until panicle initiation at 45 days when compared to that of the DS, where the mulch was not observed after 30 days). This longer duration of the mulch in the WS could have suppressed weeds to a greater extent over a longer period of time, thereby causing a beneficial effect of grain yields. The higher yield in the DWSR in the DS could be due to suppression of the weeds during early growth over the initial 30 days, the availability of abundance solar radiation and proper water management. Similar findings have also been reported by Johnson et al. (2004) that the weeds account for $49 \%$ and $47 \%$ yield reduction in 1999 WS and 2000 DS respectively due to weeds in the Senegal River delta in direct seeded, irrigated rice.

\section{Correlations}

Rice grain yield was significantly correlated with weed density (Tables 4 and 5) in both systems in both seasons at all sampling dates $(\mathrm{r}=-0.70,-0.54,-0.77,-0.67$ and -0.84 , respectively, for 28, 35 days after sowing, panicle initiation, $50 \%$ heading and harvesting in 2009 DS; $r=-0.82,-0.90,-0.79,-0.83$ and -0.75 , respectively, for 28 and 35 days after sowing, panicle initiation, $50 \%$ heading and harvesting in 2009/10 WS).

Rice grain yield was also significantly correlated with weed biomass (Tables 3 and 5) in both systems in both seasons at all sampling dates $(\mathrm{r}=-0.64,-0.79,-0.81,-0.74$ and -0.81 respectively, for 28,35 days after sowing, panicle initiation, $50 \%$ heading and harvesting in 2009 DS; $r=-0.68,-0.70,-0.81,-0.73$ and -0.76 respectively, for 28 and 35 days after sowing, panicle initiation, $50 \%$ heading and harvesting in 2009/10 WS).

Therefore, weed dry weight and weed density has the same degree of influence on rice grain yield. 


\section{CONCLUSION}

This study illustrated that the application of rice straw mulch at the rate of $4 \mathrm{t} / \mathrm{ha}$ was effective in weed management under DWSR method. However, it was not very effective in weed management in the DDSR method. Among the weed species recorded Cyperus rotundus was the most dominating species in all treatments with respect to summed dominance ratio. With increasing weed density and weed biomass, rice grain yields were reduced in both seasons in DDSR and DWSR methods.

\section{ACKNOWLEDGEMENTS}

The authors thank the Faculty of Agriculture, Rajarata University of Sri Lanka for providing the field and other facilities to conduct this research. The research work was funded by University Grants Commission, Sri Lanka.

\section{REFERENCES}

Abdelhamid, M.T., Horiuchi , T. and Oba, S. (2004). Composting of rice straw with oilseed rape cake and poultry manure and its effects on faba bean (Vicia faba L.) growth and soil properties. Bio-resource Technol. 93, 183-9.

Chung, I.M., Kim, K.H., Ahn, J.K., Lee, S.B., Kim, S.H. and Hahn, S.J. (2003). Comparison of allelopathic potential of rice leaves, straw, and hull extracts on barnyard-grass. Agron. J., 95, 1063-70.

Cornacchia, J.W., Cohen, D.B., Bowes, G.W., Schnagl R.J., and Montoya, B.L. (1984). Rice herbicides Molinate and Thiobencarb: A Water Quality Assessment. Special Project Report No. 84-4sp. California State Water Rescources Control Board, Sacramento, CA.

Ebana, K., Yan, W., Dilday, R.H., Namai, H. and Okuno, K. (2001). Variation in the allelopathy effect of rice with water soluble extract. Agron. J. 93, 12-6.

FAO. (1982). Organic materials and soil productivity. FAO Soil Bulletin. 35 GIN-FAO, Rome.

Fischer, A. J., Ateh, C. M., Bayer, D. E. and Hill, J. E. (2000). Herbicide-resistant Echinochloa oryzoides and E. phyllopogon in California Oryza sativa fields. Weed Sci. 48, 225-230.

Fujii, Y. (1992). The potential biological control of paddy weeds with allelopathy (Allelopathic effects of some varieties). Proceedings of International Symposium of Biological Control and Integrated Management of Paddy and Aquatic Weeds in Asia, pp. 305-20. National Agriculture Research Centre, Tskuba, Japan. 19-25 Oct. Food and fert. Technology Centre for the Asian and Pasific Region, China.

Hassan, S.M., Aidy, I.R., Bastawisi, A.O. and Draz, A.E. (1998). Weed management in rice using allelopathic rice varieties in Egypt. In: Olofsdotter, M. (Ed.) "Proceedings of Workshop on Allelopathy in Rice". pp. 27-37. 25-7 November, International Rice Research Institute, Manila, Philippines.

Itoh, K., Wang, G. X. and Ohba, S. (1999). Sulfonylurea resistance in Lindernia micrantha, an annual paddy weed in Japan. Weed Res. 39, 413-423. 
Hill, J. E. and Hawkins, L. S. (1996). Herbicides in United State rice production: lessons for Asia. In: R. Naylor, ed. Herbicides in Asian Rice: Transitions in Weed Management, pp. 37-52. Inst. for Int. Study, Stanford Univ., Palo Alto, CA and International Rice Research Institute, Los Baños, philippines.

Johnson, D.E., Wopereis, M.C.S., Mbodj, D., Diallo, S., Powers, S. and Haefele, S.M. (2004). Timing of weed management and yield losses due to weeds in irrigated rice in the Sahel. Field crop research. 85(1), 31-42.

Mendoza, T.C. (1989). Nutrient cycling: The key to economical farming practice. In: Proc. International Training Course on Sustainable Agriculture (ECO-Farming) pp. 67-80. Nov. 7-Dec. 8, 1988. SEARCA (DSE), 4031 College, Laguna, Philippines.

Mendoza, T.C. and Samson, R. (1999). Strategies to avoid crop residue burning in the Philippine context. p. 13. International Conference of "Frostbite and Sun Burns" Canadian International Initiatives Toward Mitigating Climate Change hosted by Internation Program (IP) of the Camadia Environmental Network (CEN) and the Salvadorn Center for Appropriate Technology (CESTA) held on 24 April-May 2.

Migo, T. R., Mercado, B. L. and De Datta, S. K. (1986). Response of Sphenoclea zeylanica to 2,4-D and other recommended herbicides for weed control in lowland rice. Philippine J. of Weed Sci. 13, 28-38.

Numata, M. (1971). Methodological problems in weed ecological research. Proceedings of Indonesian Weed Sci. Soc. Conf. 1, 41-58.

Pandey, S. and Velasco, L. (1999). Economics of direct seeding in Asia: patterns of adoption and research priorities. Int. Rice Res. Notes 24, 6-11.

Park, T. S., Kim, C. S., Park, J. P., Oh, Y. J. and Kim, K. U. (1999). Resistant biotype of Monochoria korsakowii against sulfonylurea herbicides in the reclaimed paddy fields in Korea. In: Editorial Committee for Proceedings of the 17th Asian-Pacific Weed Science Society Conference. Proceedings of the 17th Asian- Pacific Weed Science Society Conference, pp. 251-254. Asian-Pacific Weed Science Society, Bangkok, Thailand.

Patnaik, S. (1978). Natural sources of nutrients in rice soils. In Soil and Rice. P. 501-20. IRRI, Los Banos, Laguna, Philippines.

Singh, R.K., Singh, V.P. and Singh, C.V. (1994). Agronomic assessment of beushening in rainfed lowland rice cultivation, Bihar, India. Agric. Ecosyst. Environ. 51:271-280.

Stoskopf, N. C. (1985). Cereal Grain Crops. Reston Publishing, Reston, VA.

Watanabe, H., Ismail, M. Z. and Ho, N. A. (1997). Response of 2,4-D resistant biotype of Fimbristylis miliacea (L.)vahl to 2,4-D dimethylamine and its distribution in the Muda Plain, peninsular Malaysia. Weed Res. 42, 240-249.

Watanabe, I. (1978). Biological nitrogin fixation in rice soil. In Soil and Rice. IRRI, Los Baños, Laguna, Philippines.

Yoshida, S. (1981). Fundamentals of Rice Crop Science. Los Baños, Laguna, Philippines, International Rice Research Institute. p. 269. 